\title{
The institutional logics of local government budget in Indonesia
}

\author{
Ade Palupi $^{*}$, and Refinaldo Febiandra ${ }^{1}$ \\ ${ }^{1}$ Department of Accounting, Airlangga University, Indonesia
}

\begin{abstract}
This study asks how and why a local government settings budget. It aims to deliver an understanding on how a government entity perceives that budget is important element to manage public expenditures. It uses the S local government in Indonesia as a case study. This study applies Institutional Logics Theory as a theoretical framework in order to analyze data. Data is collected by interviewing seven key persons who directly involves in budgeting process. This research shows that the budgeting process includes determining the purposes of annual budget, setting up planned programs and actvities, determining the amount of revenue that will be collected, allocating resources to expenditures and setting up standar pricing. Some important points in the budgeting process are identified. Those are considering political aspect to determine local tax rate, focusing on competition with other local governments, fulfilling the political promise of local government leader to the constituents, involving community to determine planned program and activities, and allocating resources based on community basic needs. This study concludes that those points develop the institutional logics of politic and managerial in budget setting process.
\end{abstract}

\section{Introduction}

This study is about on how and why a local governemnt should develop a budget. Some previous research show that governments in some countries in southern hemisphere apply accounting tools in government entities because of external pressures rather than internal organization needs $[1,5,7]$. Therefore, this study attempts to find out the logical thinking on why budget is important to government entities.

This research aims to deliver an understanding on how a government entity perceives that budget is important element to manage public expenditures. It is important as some countries still apply incremental and line item budgeting system although government reforms budgeting process into performance based management.

The $\mathrm{S}$ local government in Indonesia is applied as a case study. The Indonesian government rules the implementation of performance based budgeting to be applied by government agencies. However, it has not succeeded yet because of a lack of human resources and inadequate IT system. Based on this condition, this study take an Indonesian local government to examine on how performance based budgeting is implemented to develop a local governement budget.

*Corresponding author: adepalupy@yahoo.com 


\section{Literature Review}

Diamond [6] suggests on how government should implement performance based budgeting. Measuring the efficiency of budget performance requires a change in mindsets at the highest political level and the measuring process should be accepted by middle and lower management levels. In addition, top level bureaucrats must set up firstly the necessary legislative, financial, organizational, personnel and information frameworks for budget implementation. The involvement of citizen is important to ensure that data used to set up budget is credible and fit with public needs. In addition, a new sistem of accountability and incentives need to be introduced to accelerating the suceess of performance based budgeting.

However, performance based budgeting is problematic. The problems are (1) it sometimes does not provide a clear link between performance and fund allocation; (2) performance measurement does not constitute an effective basis for decision making; (3) and budget fails to identify 'who' is responsible for performance and resource spending [4].

The complexity of organisation characteristic influences on how and why budget is developed. A study of French theathers shows that the teathers that are subsidied by the French government experienced a tension when preparing the budget [3]. A tension is occured because the organisation has two important opposed objectives which are escalating original artistic value in producing cultural arts, on the other hand, it has to promote eficiency to manage its fund. As the theathers are funded by the government, the study finds that the budget also as a media to fulfill the government interest [3].

Ezzamel et al [8] also investigates why budget is important in education sector in England and Wales. Similar to Amans et al [3]'s study, Ezzamel et al [8] finds there is a tension of logical thinking during budget setting process. That the budget relates to the number of students, budget motivates the education institutions to go for competition to get a larger number of students. However, in the name of effieciency, the education institutions have to cut their expenditures including the amount of teachers' salaries, as a consequence, they should reduce the number of teachers. The study also shows that the interest of government in requiring the standard salary rate for teachers and increasing the number of teachers leads a conflict during budgeting process.

Those previous research indicate implementing performance based budget compels the change of organisational context. Indeed, applying performance based budgeting requires profesionalism in planning, financing and accounting. However, some countries that having a lack of resources, apply performance based budgeting as it is motivated by external pressures. For example, the Indonesian government encounters some problems to accelerate the budgeting reform as the reform is pushed by external pressures which are government regulations and donor agencies [7]. The perception that managing external institutions with significant actors is more important than to fulfilling the need of organisation itself is the main reason on why the Bangladeshi state-owned enterprises apply performance based budgeting, as a result the budget is relatively uncoupled from detailed aspects of the organizational tasks [2].

\section{Research framework}

This study applies the institutional logics theory [9] as a research framework. Thornton and Ocasio [9] defined institutional logics as socially constructed, historical patterns of material practices, assumptions, values, beliefs, and rules by which individuals produce and reproduce their material subsistence, organize time and space, and provide meaning to their social reality. The basic idea of institutional logics is to link between individual agency, 
cognition and socially constructed institutional practices and rule structures. There is a connection between individual choices to do something and their broader institutional orders. The institutional logics theory is capable to explain on how and why people conduct in particular actions in organisations.

As society institutional order has both material and cultural characteristics, institutional logic recognizes that institutions are developing and changing as a result of interplay between material and cultural substances those embedded in individual who locate in organisation. When the structure of society is changed, people will respond differently in accordance to material and cultural capital they have. Practices are a result of the interplay between individual agency and their institutional context.

Likewise, when organisational culture changes, institutional logics on how organizations live could be changed, as a consequence, there would be competition between prevailing and new institusional order. For example, Ezzamel et al [8] studies the change of budgeting sytem in the English and Wales' schools as the UK government issued a new education reform act. As its institutional order was changed by embracing new public management concept, the prevailing institutional logic of education field that was teaching professionalism logic was changed to business logic. The tension of these both logics is evidenced in school budgetary practices. Business logic that dominantly underlies the budget setting process drives the change individual tasks within schools whilts the logic of teaching professionalism does not become a dominant value anymore.

This study applies institutional logics theory to examine how budgetary practices shifts from tradisional to performance based bugeting in a complex organisation that is a local government in an emerging country. By using the theory, it will identify what kind of logics that brought by new budgetary practices and how the new logics competed with prevailing logics and how actors within organisation encounter the conflict of logics in new budgetary system.

\section{Research Method}

Data was collected by doing in-depth-interview and documentation. All of interviewees are seven persons who are the member of budget comittee. They are the head of revenue agency who is responsible to determine the amount of revenue in the budget; the head of internal auditor; the manager of tax and retribution who assist the head of revenue to calculate revenue budget; the manager of assets; two managers of public works agency as a key person to determine expenditure budget.

All interviews was recorded and transcribed. Then, all interview transcripts and documentation were read in order to find stories on how local government budget is developed. Data is categorized into themes which are the change of budget system; the budgetary practice; determining revenue and expenditure budget. Each theme, then, is analyzed.

\section{Findings}

\subsection{The change of budget system}

The Indonesian government reforms its governement budgeting system based on the law No. 17/2003. The reform includes the change of budgeting system in local government that it is ruled by Domestic Affairs Ministry Regulation No. 21/2011. The regulations state that government budget should apply the method of performance based budget to replace the practice of incremental based budget. It also rules that the process of budgeting includes the 
development planning discussion to accommodate community voice in a region. The aim of community discussion is identifying community needs in term to determine target ouputs which are the significant point in performance based budgeting.

The reform brings some changes in local government. It changes the structure of budget, the legal system of budget and the change of information technology. Those changes affect on how government entities to set their budgets. The followings explain how the S local government in East Java Province, Indonesia, set its budget.

\subsection{The budgetary practice}

Bottom up, top bottom and participative approaches are applied by the $\mathrm{S}$ local government to set its budget. Bottom-up approach accumulates community needs through the development planning discussion. Participative approach is conducted by identifying what programs and activities that the government agencies within $\mathrm{S}$ local government will do for the following year. Top bottom approach means budget should also accomodate the vision of district head. According to the respondents:

"Our budget preparation links to the district head's vision and missions that have already stated in his political champaign" (The Head of Asset Management Agency)

"We conducted the development planning discussion to identify the advantages and disadvantages of development programs in villages. We should focus on how deploy public fund to accomodate community needs that should be the development priority. However, there are too many needs but our public fund is not enough. Therefore, there is a limitation to fullfill people's needs" (Internal Auditor)

"If we find limitation on the amount of public fund in setting budget, we will cut the programs and activities proposed by the government agencies. We will not delete the program and activities that required by community through the development planning discussion. (Head of Parks and Sanitation Agency)

From the interviews, this study sees that the budget preparation is about to fulfilling the political intention of district leader. The budget reflects the vision of dictrict leader during his/her political campaign. Also, the budget put people satisfiction as a priority instead of what the local government management should do to achieve its goals. It could link that satisfying people is considered to fulfilling district leaders' constituent so that their political position is safe. However, the Indonesia regulation states that local government's vision and objectives are as same as the district leaders' vision that announced during political champaign. This regulation indeed distract on how the budget is made. The budget should bring the value of efficiency on how to consume public fund instead of focusing on satisfying constituents and fulfilling the political promise of district leader.

The interview also shows that the $\mathrm{S}$ local government finds the limitation of public fund to finance its programs and activities. It means that the budget should prioritize on how the total amount of revenue is allocated to cover spending.

\subsection{Setting revenue budget}

The Indonesian regulations state that local government revenue budget should consist of three accounts which are district revenue, transfer and other revenues. District revenue accounts for local taxes and retributions collection. Transfer account records transfer funds from the central and province governments. Other revenues account may record dividend revenue as it is a return from local government investment in government business 
enterprises. Therefore, district revenue is the most important aspect of local government revenue budget as it is a representation the sustainability of financial capability.

The $\mathrm{S}$ local government plans its revenue budget by determining the local tax rate as the Head of Finance Agency says:

"we consider other local governments' economic condition such as Banyuwangi, Jember and Bondowoso and the social and economic condition of local people to define local tax rates"

"we asked help to the supervision for development financing body to calculate the potential amount of district revenue budget and the district leader determines the amount stated in revenue budget”

"we also justify the amount of budget revenue in front of the local parliament"

This study implies that the political aspect of budget is a priority. Local government challenges other local governments as competitors to set local tax rates. The main reason is perhaps to attract more investors or business in S. The potential local taxes and retributions should be the basic reference to determine the amount of revenue budget instead of the district leader's decision. This condition might degrade the quality of budget as the district leader might hesitate to take risk. The number of tax revenue is usually set lower than the potential economic capacity. It means the performance of district leader in attaining revenue target is easier and the performance report would look good. Thus, determining district revenue is a kind of political logic instead of managerial logic.

\subsection{Setting expenditures}

Another important aspect on how to prepare budget in the Indonesian government is setting the total amount of expenditures. Mostly local governments in Indonesia find challenges covering all expenditures with local taxes. Therefore, they rely on the transfer fund from the central and province governments. According to the head of park and sanitation agency:

"the programs of government agencies is defined by the agencies' tasks and responsibilities. For example, waste disposal program. We predict how many garbage trucks are needed so we know how much liters of gasoline are required and how many persons needed to operate waste disposal program. Thus, we know how much fund should be available to conduct waste disposal program”,

"for basic needs such as waste disposal program, street light and sanitation, we try all those programs can be covered by available fund so that we do not cut the program activities. But sometimes, it happens"

This study mentions the managerial aspect of budget is also considered in setting expenditure budget in the S local government. The total amount of expenditure is based on the output target of program that link to basic community needs. Therefore, the value of program effectiveness is a logic in budgeting process.

\section{Concluding remarks}

Thornton and Ocasio's [9] theory on institutional logics states that practices are motivated by value, beliefs or rules. By applying this theory to find out on how the $\mathrm{S}$ local government budget is produced, this study shows that budgeting process is a kind of politic and managerial logic. 
The logic of politic in budgeting process can be seen on the process of revenue budget setting. The budget is a decision of political leader and as a tool to fulfill political commitment. The logic of managerial is also occurred expenditure budgeting process. Management accounting concept is applied to determine the cost of program by considering the total number of target output as a priority. This study evidences that the $\mathrm{S}$ local government budgeting combines the logic of politic and managerial.

Conflict between those logics is happened. First, the conflict is occurred between using the potential calculation of local economic versus the district leader decision to set the total amount of revenue budget. Second, the conflict also occurs in determining the total amount of spending budget. The local government agencies main tasks and public needs should be priorities but it cannot because of funding limitation. This study finds logic of politics is dominant than the logics of managerial in budgeting process.

\section{References}

1. Adhikari, P. Kuruppu, C. and Matilal, S. Dissemination and institutionalization of public sector accounting reforms in less developed countries: A comparative study of the Nepalese and Sri Lankan central governments, Accounting Forum 37, pp. (2013) 213-230. (2013).

2. Alam, M. Budgetary process in uncertain contexts: a study of state-owned enterprises in Bangladesh, Management Accounting Research, Vol. 8(2), pp. 147-167. (1997).

3. Amans, P., Chapelon, A. M., \& Dubus, F. V. Budgeting in institutional complexity: The case of performing arts organizations. Management Accounting Research, 27( ), 47-66. (2015).

4. Andrews, M. Performance Based Budgeting Reforms: Progress, Problems and Pointers, in Anwar Shah (ed) Handbook on Public Sector Performance Reviews, Vol. 1: Ensuring Accountability When There is No Bottom Line. (2003).

5. Azmi, A.H., and Mohamed, N. Readiness of Malaysian public sector employees in moving towards accrual accounting for improve accountability: The case of Ministry of Education (MOE), International Conference on Accounting Studies 2014, ICAS 2014, 18-19 August 2014, Kuala Lumpur, Malaysia. (2014).

6. Diamond, J. From Program to Performing Budgeting the Challenge for Emerging Market Economies, IMF Working Paper. (2003).

7. Djamhuri, A. A Case Study Of Governmental Accounting And Budgeting Reform At Local Authority In Indonesia: An Institutionalist Perspective, Thesis submitted in fulfillment of the requirements For the degree of Doctor Philosophy, School of Management Universiti Sains Malaysia. (2009).

8. Ezzamel, M., Robson, K., \& Stapleton, P. The logics of budgeting: Theorization and practice variation in the educational field. Accounting, Organizations and Society, Vol. 37, 281-303. (2012).

9. Thornton, P.H. and Ocasio, W. Institutional Logics, in Royston Greenwood, Christine Oliver, Kerstin Sahlin and Roy Suddaby (eds.) Handbook of Organizational Institutionalism, CA: Sage. (2008). 